\title{
HLA-B*1501 Positive Cells Present
}

National Cancer Institute

\section{Source}

National Cancer Institute. HLA-B*1501 Positive Cells Present. NCI Thesaurus. Code C154112.

An indication that cells expressing HLA-B*1501 have been detected in a sample. 